\title{
Faktor-Faktor yang Mempengaruhi Pengetahuan Ibu Tentang Terjadinya Stomatitis pada Balita di Lingkungan I Kelurahan Sigalangan Kecamatan Batang Angkola Tahun 2018
}

\author{
Desi Meliana Gultom \\ Program Studi Keperawatan, Institut Teknologi dan Kesehatan Sumatera Utara
}

\section{Info Artikel}

\section{Article history:}

Diterima 09-06-2021

Revisi 28-06-2021

Disetujui 10-07-2021

\section{Kata kunci:}

Pengetahuan,

ibu,

stomatitis pada balita.

\begin{abstract}
A B S T R A K
Stomatitis (sariawan) adalah peradangan pada mukosa (lapisan lendir) mulut yang bisa mengenai mukosa pipi,dengan langit-langit dan stomatitis juga merupakan infeksi yang dapat terjadi secara tersendiri atau bisa merupakan bagian dari sistemik, menurut stomatitis tergantung daerah populasi yang diteliti bersekitar 15-20\% dari populasi seluruh dunia. Di Indonesia di jumpai khasus stomatitis pada balita sebanyak 26,6\%, menurut Dr Rini Cipto Mungunkusumo sariawan pada bayi disebabkan jamur sebanyak 2-5\% neonatus normal. Menurut penelitian dr, Suparyanto di Poli Klinik Jombang pada bulan Januari sampai Juni 2017 terdapat 237 balita yang terkena stomatitis,. Tujuan penelitian ini untuk Mengetahui Faktor-Faktor tentang terjadinya stomatitis pada balita di Lingkungan Kelurahan Sigalangan Kecamatan Batang Angkola Tahun 2018. Waktu penelitian Januari sampai bulan April 2018. Jenis penelitian ini adalah kuantitatif dengan desain dekrsritif dan jumlah sampel 31 responden ibu yang mempunyai balita. Pengambilan sampel dilakukan dengan metode total sampling. Jenis data yang digunakan dalam penelitian ini adalah data primer dan sekunder dengan menggunakan kuesoner. Hasil penelitian berdasarkan umur mayoritas umur 19-23 tahun sebanyak 11 responden (35,5\%), minoritas umur 29-33 sebanyak 11 responden $(35,5 \%)$, berdasarkan pendidikan mayoritas SD sebanyak 11 responden (35,5\%), minoritas SMP sebanyak 4 responden (12,9\%), berdasarkan pekerjaan mayoritas petani sebanyak 18 responden $(58 \%)$, minoritas wiraswasta sebanyak 4 responden $(13 \%)$, berdasarkan sumber informasi mayoritas dari media elektronik sebanyak 14 responden $(45,2 \%)$, minoritas dari petugas kesehatan sebanyak 8 responden $(25,8 \%)$. Berdasarkan peneliti ini disimpulkan bahwa pengetahuan ibu yang mempunyai balita tentang stomatitis di lingkungan I kelurahan sigalangan kecamatan batang angkola tahun 2018 berpengetahuan cukup yang di pengaruhi oleh umur, pendidikan, pekerjaan, sumber informasi. Saran yang diharapkan kepada petugas kesehatan untuk lebih banyak memberikan informasi dan penyuluhan yang lebih jelas tentang stomatitis pada balita, diharapkan pada ibu untuk meningkatkan pengetahuan tentang stomatitis pada balita melalui media massa, elektronik serta mengikuti penyuluhan yang dilakukan oleh petugas kesehatan.
\end{abstract}

\section{Koresponden Penulis:}

Desi Meliana Gultom,

Program Studi Keperawatan, Institut Teknologi dan Kesehatan Sumatera Utara,

Jl. Trans Sumatera Bukittinggi - Padang Sidempuan, Sihitang, Padangsidimpuan Tenggara, Kota Padang

Sidempuan, Sumatera Utara 22733

Email: desimeliana@gmail.com

\section{PENDAHULUAN}

Stomatitis atau sariawan adalah peradangan pada mukosa (lapisan lender) mulut yang bias mengenai mukosa pipi, dengan langit-langit dan Stomatitis juga merupakan infeksi yang dapat terjadi secara tersendiri atau bisa merupakan bagian dari penyakit sistemik (Arif, 2010). 
Sariawan (oral trush) ini juga sering dijumpai pada bayi dan balita yang minum susu dengan botol/dot, dan balita yang mengisap dot kompeng yang tidak di perhatikan kebersihannya mulutnya akan terkena jamur candida albicans (Rochman, 2011).

Prevalensi stomatitis bervariasi tergantung pada daerah populasi yang diteliti. Angka prevalensi stomatitis pada balita berkisar 15-25\% dari populasi penduduk di seluruh dunia. Penelitian telah menemukan terjadinya stomatitis pada balita sekitar 2\% di Swedia (1985) 1,9\% di Spanyol (2002) dan 0,5\% di Malaysia (2000). Stomatitis tampaknya jarang terjadi di Bedouins Kuwaiti yaitu sekitar 5\% dan ditemukan 0,1\% pada masyarakat India di Malaysia (Suparyanto, 2012).

Di Indonesia belum diketahui berapa prevalensi stomatitis di masyarakat, tetapi dari data klinik penyakit mulut di rumah sakit Ciptomangun Kusumo tahun 2010 sampai dengan 2013 dijumpai kasus stomatitis pada balita sebanyak 26,6\%, periode 2005-2006 didapatkan prevalensi stomatitis dari 101 pasien terdapat kasus stomatitis pada balita umur 1-5 17,3\%.3 (Suparyanto,2012 ) .

Menurut dr. Rini Sekartini, SpA dari RSUPN Cipto Mangunkusumo, umumnya sariawan yang terjadi pada bayi disebabkan oleh jamur sedangkan pada anak dan balita disebabkan oleh trauma dan juga jamur. Sariawan yang paling yang paling umum dilibatkan pada penyakit ini adalah candida albicans atau monoliasis. Sariawan atau candidiasis oral adalah infeksi supersialis membran mucosa yang mengenai sekitar 2-5\% neonatus normal. Bayi mendapat jamur ini dari ibunya pada saat persalinan yang terinfeksi kandida dan akibat penggunaan antibiotik terutama pada umur 1 tahun (Anonim, 2011).

Menurut penelitian dr. Suparyanto di Poli Klinik anak RSUD Jombang di dapatkan data pada bulan Januari-Juni 2011 terdapat 137 bayi usia 0-1 tahun yang menderita stomatitis, dan dari 7 ibu yang memepunyai bayi usi 0-1 tahun 5 ibu mengetahui tantang oral hygiene tapi tidak berani melekukan dan 2 lainya tidak tahu tentang oral hygiene (Suparyanto, 2012).

Penelitian Charles Darwin di RSU Panyabungan Tapanuli Selatan bahwa dari 105 balita yang dilakukan pemeriksaan rongga mulut ditemukan pada 32 balita $(23,70 \%)$ mengalmi sariawan white coated tongue di temui pada 26 balita ( $19,26 \%$ ). Pemeriksaan juga di lakukan keluhan mencret di dapatkan adanya candida albican pada 28 balita $(44,44 \%)$ dan balita ini juga menderita sariawan pada mulut (Anonim, 2011).

Bedasarkan survey awal yang dilakukan Di Lingkungan I Kelurahan Sigalangan Kecamatan Batang Angkola Tahun 2018 terdapat 31 0rang ibu yang mempunyai balita dari $10 \mathrm{ibu}$ yang di wawancarai hanya 5 orang ibu yang mengetahui tentang terjadinya stomatitis pada balita, dan 5 orang ibu lainya tidak mengetahui tentang terjadinya stomatitis (sariawan) pada balita, sedangkan Di Lingkungan II Kelurahan Sigalangan Kecamatan Batang Angkola terdapat 44 orang ibu yang mempunyai balita dari 10 orang ibu yang di wawancarai hanya 8 orang ibu yang mengetahui tentang terjadinya stomatitis pada balita. dan 2 orang ibu lainya tidak mengetahui tentang terjadinya stomatitis pada balita. Sehingga peneliti tertarik untuk melekukan penelitian Di Lingkungan I Sigalangan Kecamatan Batang Angkola tahun 2018.

\section{METODE PENELITIAN}

\subsection{Kerangka Konsep}

Kerangka konsep adalah suatu hubungan atau kaitan antara konsep satu terhadap konsep lain dari masalah yang diteliti sesuai dengan apa yang telah diuraikan pada studi perpustakaan (Notoatmodjo, 2005). Berdasarkan uraian teori dan perumusan masalah, maka peneliti menggambarkan kerangka konsep sebagai berikut :

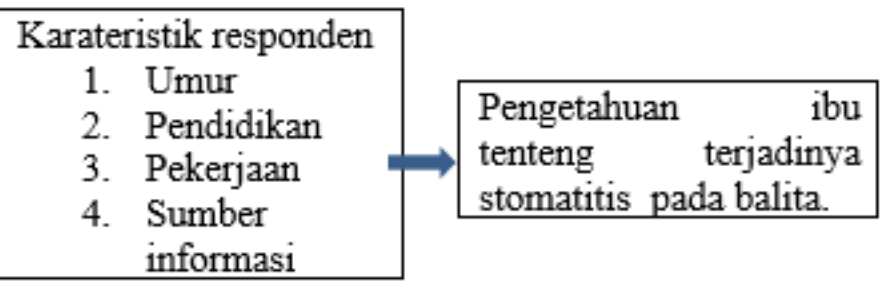

Gambar 1. Variabel Independent dan Variabel Dependent

Keterangan : Variabel yang akan di teliti dari penelitian adalah :

JURKESMAS : Jurnal Kesehatan Masyarakat, Vol. 1, No. 1, Juli 2021: 65 - 73 
a. Variabel Independent, variable sebab atau variable yang memepengaruhi yaitu krateristik ibu berdasarkan umur,pendidikan pekerjaan, dan sumber informasi.

b. Variabel Dependent, variable akibat atau variable yang di pengaruhi yaitu pengetahuan ibu tentang terjadinya stomatitis pada balita.

\subsection{Jenis Dan Disains Penelitian}

\section{A. Jenis Penelitian}

Jenis penelitian ini yang digunakan kuantitatif yaitu untuk mengetahui faktor-faktor yang mempengaruhi pengetahuan pengetahuan ibu tentang terjadinya stomatitis pada balita di Lingkungan I Kelurahan Sigalangan Kecamatan Batang Angkola Tahun 2018.

\section{B. Desain Penelitian}

Desain yang digunakan dalam penelitian ini menggunakan metode penelitian deskriptif yaitu untuk mengetahui bagaimana faktor-faktor yang memepengaruhi pengetahuan ibu tentang terjadinya stomatitis pada balita di Lingkungan I Kelurahan Sigalangan Kecamatan Batang Angkola Tahun 2018.

\subsection{Populasi dan Sampel}

\section{A. Populasi}

Populasi adalah keseluruhan objek penelitian atau objek yang diteliti (Arikunto, 2006) dalam penelitian yang menjadi Populasi adalah seluruh ibu yang memepunyai balita Di Lingkungan I Kelurahan Sigalangan Kecamatan Batang Angkola Tahun 2018 yang berjumlah 31 Orang ibu yang memepunyai balita.

\section{B. Sampel}

Sampel adalah sebagian yang diambil dari keseluruhan objek yang diteliti di anggap mewakili seluruh populasi. Sampel menurut arikunto (2006), jika populasi lebihdari 100 maka pengambilan sampel boleh $10 \%-15 \%$ atau $20 \%$ - 25\% dari jumlah populasi. Jika populasi kurang dari100 maka keseluruhan populasi dijadikan sampel. Sampel dari penelitian ini sebanyak 31 orang ibu yang mempunyai balita. dengan menggunakan tehknik total sampling.

\subsection{Jenis dan Cara Pengumpulan Data}

\section{A. Jenis data Jenis Data}

Jenis data yang digunakan dalam penelitian ini adalah :

1. Data primer adalah data yang diperoleh langsung oleh sipeneliti dari responden dengan membagi kuesioner sebanyak 20 pertanyaan.

2. Data sekunder adalah data yang diperoleh dari tempat penelitian yaitu di Lingkungan I Kelurahan Sigalangan kecamatan batang angkola Tahun 2018

\section{B. Cara Pengumpulan Data}

Adapun teknik dalam pengumpulan data adalah :

1. Angket (kuesoner)

Angket atau kuesoner adalah sejumlah petanyaan tertulis yang digunakan untuk memperoleh informasi dari responden dalam arti laporan tentang pribadinya atau hal-hal yang diketahui.

2. Pengukuran

Salah satu cara mengukur data dengn menggunakan Skala Guttman yaitu skala pengukuran dengn jawaban Benar atau salah. Dengan membagikan kepada responden sebanyak 20 soal. Setiap jawaban yang benar di beri nilai 1 dan salah satu diberi 0 .

3. Wawancara

Wawancara adalah suatu metode yang dipergunakan untuk mengumpulkan data, dimana peneliti mendapat keterangan atau informasi secara lisan dari seseorang sasaran penelitian (responden), atau bercakap-cakap berhadapan muka dengan orang tersebut (face to face)

(Notoatmodjo, 2010).

\subsection{Pengolahan dan Analisa Data}

\section{A. Pengolahan Data}

Data-data yang diperoleh dan di kumpulkan kemudian diolah secara manual dengn langkahlangkah sebgai berikut :

1. Editing (edit) 
Dilakukan pengecakan akan kelengkapan kuesioner yang telah masuk apakah semua pertanyaan telah diisi, apabila terdapat kesalahan atau kekurangan dalam pengumpaulan data, maka akan di perbaiki serta dilakukan pendataan ulang.

2. Coding (kode)

Pemberian kode atau tanda pada setiap data yang telah dikumpulkan untuk mempermudah memasuki data ke dalam tabel.

3. Skoring (skor)

Pada kuesioner pengukuran, sebelumnya harus mensentukan katogori-katogori baik, cukup, kurang dan terlebih dan menentukan kriteria-kriteria tersebut.

4. Tabulating (table)

Analisa data yang yang telah disimpulkan setiap petanyaan yang bener akan diberikan skor dan jawaban yang salah tidak ada nilai (0). Kemuian menetukan persentase jawab an dari setiap responden (Notoatmodjo, 2010).

\subsection{Analisa Data}

Analisa data dilakukan secara deskriptif dengan melihat presentase data yang telah dikumpulkan dan disajikan dalam tabel distribusi, analisa data kemudian dilanjutkan dengan membahas penelitian (Sudijono, 2008).

$$
\mathrm{P}=\frac{f}{N} \times 100 \%
$$

Keterangan :

$\mathrm{P} \quad=$ Persentase

$\mathrm{f} \quad=$ Frekuensi

$\mathrm{N} \quad=$ Jumlah responden

\section{HASIL DAN PEMBAHASAN}

\subsection{Hasil}

Penelitian ini dilakukan pada tanggal 19 Mei 2018 dengan objek penelitian adalah ibu yang mempunyai balita di Lingkungan I Kelurahan Sigalangan Kecamatan Batang Angkola dengan sampel 31 responden. Penelitian ini dilakukan untuk mengetahui Faktor-faktor Yang Mempengaruhi Pengetahuan Ibu Tentang Terjadinya Stomatitis Pada Balita di Lingkungan I Kelurahan Sigalangan Kecamatan Batang Angkola, dengan hasil penelitian sebagai berikut :

\section{A. Frekuensi Responden Berdasarkan Pengetahuan}

Tabel 1. Frekuensi Responden Tentang Terjadinya Stomatitis Pada Balita Berdasarkan Pengetahuan di Lingkungan I Kelurahan Sigalangan Kecamatan Batang Angkola Tahun 2018

\begin{tabular}{cccc}
\hline No & $\begin{array}{c}\text { Kategori } \\
\text { Pengetahuan }\end{array}$ & Frekuensi & Persentase (\%) \\
1. & Baik & 5 & $16,1 \%$ \\
2. & Cukup & 20 & $64,5 \%$ \\
3. & Kurang & 6 & $19,4 \%$ \\
& Jumlah & $\mathbf{3 1}$ & $\mathbf{1 0 0 \%}$ \\
\hline
\end{tabular}

Berdasarkan Tabel 1 di atas menunjukkan bahwa dari 31 responden yang diteliti yang mempunyai pengetahuan baik berjumlah 5 responden $(16,1 \%)$, berpengetahuan cukup berjumlah 20 responden $(64,5 \%)$, dan yang berpengetahuan kurang berjumlah 6 responden $(19,4 \%)$.

\section{B. Frekuensi Responden Berdasarkan Umur}

Tabel 2. Frekuensi Responden Tentang Terjadinya Stomatitis Pada Balita Berdasarkan Umur di Lingkungan I Kelurahan Sigalangan Kecamatan Batang Angkola Tahun 2018

\begin{tabular}{lccc}
\hline No & \multicolumn{1}{c}{ Umur } & Frekuensi & $\begin{array}{c}\text { Persentase } \\
(\boldsymbol{\%})\end{array}$ \\
1. & $19-23$ Tahun & 11 & $35,5 \%$ \\
2. & $24-28$ Tahun & 11 & $35,5 \%$ \\
3. & 29- 33 Tahun & 9 & $29 \%$ \\
& Jumlah & $\mathbf{3 1}$ & $\mathbf{1 0 0 \%}$ \\
\hline
\end{tabular}

JURKESMAS : Jurnal Kesehatan Masyarakat, Vol. 1, No. 1, Juli 2021: 65 - 73 
Berdasarkan Tabel 2 di atas menunjukkan bahwa dari 31 responden yang berumur 19-23 tahun berjumlah 11 responden (35,5\%), yang berumur $24-28$ tahun berjumlah 11 responden $(35,5 \%)$, yang berumur 29-33 tahun berjumlah 9 responden (29\%).

\section{Frekuensi Responden Berdasarkan Pendidikan}

Tabel 3. Frekuensi Responden Tentang Terjadinya Stomatitis pada balita Berdasarkan Pendidikan di Lingkungan I Kelurahan SigalanganKecamatan Batang Angkola Tahun 2018

\begin{tabular}{cccc}
\hline No & Pendidikan & Frekuensi & Persentase (\%) \\
1. & SD & 11 & $35,5 \%$ \\
2. & SMP & 4 & $12,9 \%$ \\
3. & SMA & 7 & $22,6 \%$ \\
4. & P T & 9 & $29 \%$ \\
& Jumlah & $\mathbf{3 1}$ & $\mathbf{1 0 0 \%}$ \\
\hline
\end{tabular}

Berdasarkan Tabel 3 di atas menunjukkan bahwa dari 31 responden yang diteliti berpendidikan SD berjumlah 11 responden $(35,5 \%)$, yang berpendidikan SMP berjumlah 4 responden $(12,9 \%)$, yang berpendidikan SMA berjumlah 7 responden $(22,6 \%)$, dan yang berpendidikan Perguruan Tinggi 9 responden $(29 \%)$.

\section{Frekuensi Responden Berdasarkan Pekerjaan}

Tabel 4. Frekuensi Responden Tentang Terjadinya Stomatitis pada balita Berdasarkan Pekerjaan di Lingkungan I Kelurahan SigalanganKecamatan Batang Angkola Tahun 2018

\begin{tabular}{cccc}
\hline No & Pekerjaan & Frekuensi & Persentase (\%) \\
1. & Petani & 18 & $58 \%$ \\
2. & PNS & 9 & $29 \%$ \\
3. & Wiraswasta & 4 & $13 \%$ \\
& Jumlah & $\mathbf{3 1}$ & $\mathbf{1 0 0 \%}$ \\
\hline
\end{tabular}

Berdasarkan Tabel 4 di atas menunjukkan bahwa dari 31 responden yang diteliti pekerjaan sebagai Petani berjumlah 18 responden (58\%), pekerjaan sebagai PNS berjumlah 9 responden (29\%), dan yang bekerja sebagai Wiraswasta berjumlah 4 responden (13\%).

\section{E. Frekuensi Responden Berdasarkan Sumber Informasi}

Tabel 5. Frekuensi Responden Tentang Terjadinya Stomatitis pada balita Berdasarkan Sumber Informasi di Lingkungan I Kelurahan SigalanganKecamatan Batang Angkola Tahun 2018

\begin{tabular}{cccc} 
No & Sumber Informasi & Frekuensi & Persentase (\%) \\
1. & Media Cetak & 9 & $29 \%$ \\
2. & Media Elektronik & 14 & $45,2 \%$ \\
3. & Petugas Kesehatan & 8 & $25,8 \%$ \\
& Jumlah & $\mathbf{3 1}$ & $\mathbf{1 0 0 \%}$ \\
\hline
\end{tabular}

Berdasarkan tabel 5 di atas menunjukkan bahwa dari 31 responden yang diteliti menyebutkan Sumber Informasinya dari Media Cetak berjumlah 9 responden (29\%), Sumber Informasinya dari Media Elektronik berjumlah 14 responden $(45,2 \%)$, dan yang Sumber Informasinya dari Petugas Kesehatan berjumlah 8 responden $(25,8 \%)$.

\section{Data Khusus}

\section{F. Distribusi Responden Berdasarkan Umur}

Tabel 6. Distribusi Frekuensi Responden Tentang Terjadinya Stomatitis pada balita Berdasarkan Umur di Lingkungan I Kelurahan Sigalangan Kecamatan Batang Angkola Tahun 2018

\begin{tabular}{|c|c|c|c|c|c|c|c|c|c|}
\hline \multirow{3}{*}{ No } & \multirow{3}{*}{ Umur } & \multicolumn{6}{|c|}{ Pengetahuan } & \multicolumn{2}{|c|}{ Jumlah } \\
\hline & & \multicolumn{2}{|c|}{ Baik } & \multicolumn{2}{|c|}{ Cukup } & \multicolumn{2}{|c|}{ Kurang } & \multirow{2}{*}{$\mathbf{F}$} & \multirow{2}{*}{$\%$} \\
\hline & & $\mathbf{F}$ & $\%$ & $\mathbf{F}$ & $\%$ & $\mathbf{F}$ & $\%$ & & \\
\hline 1 & $19-23$ & 0 & $0 \%$ & 8 & $\begin{array}{c}25,8 \\
\%\end{array}$ & 3 & $9,7 \%$ & 11 & $\begin{array}{c}35,5 \\
\%\end{array}$ \\
\hline 2 & $24-28$ & 2 & $\begin{array}{c}6,5 \\
\%\end{array}$ & 7 & $\begin{array}{c}22,5 \\
\%\end{array}$ & 2 & $6,5 \%$ & 11 & $\begin{array}{c}35,5 \\
\%\end{array}$ \\
\hline 3 & $29-33$ & 5 & $\begin{array}{c}16,1 \\
\%\end{array}$ & 3 & $9,7 \%$ & 1 & $3,2 \%$ & 9 & $29 \%$ \\
\hline
\end{tabular}




\begin{tabular}{ccccccccc}
\hline Jumlah & 7 & $\begin{array}{c}22,6 \\
\%\end{array}$ & 18 & $58 \%$ & 6 & $\begin{array}{c}19,4 \\
\%\end{array}$ & 31 & $\begin{array}{c}100 \\
\%\end{array}$ \\
\hline
\end{tabular}

Berdasarkan Tabel 6 di atas dapat dilihat bahwa dari 31 responden yang berumur 19-23 tahun sebanyak 11responden ( $35,5 \%)$, dengan pengetahuan baik sebanyak tidak ada, pengetahuan cukup sebanyak 8 responden $(25,8 \%)$, pengetahuan kurang sebanyak 3 responden $(9,7 \%)$. Responden yang berumur 24-28 tahun sebanyak 11 responden (35,5\%), pengetahuan baik sebanyak 2 responden $(6,5 \%)$, pengetahuan cukup sebanyak 3 responden $(9,7 \%)$, pengetahuan kurang sebanyak 2 responden (6,5\%). Responden yang berumur 29-33 tahun sebanyak 9 responden (29\%), dengan pengetahuan baik sebanyak 5 responden $(16,1 \%)$, pengetahuan cukup sebanyak 3 responden $(9,7 \%)$, pengetahuan kurang sebanyak 1 responden $(3,2 \%)$.

G. Distribusi Responden Berdasarkan Pendidikan

Tabel 7. Distribusi Frekuensi Responden Tentang Terjadinya Stomatitis pada balita Berdasarkan Pendidikan di Lingkungan I KelurahanSigalangan Kecamatan Batang Angkola Tahun 2018

\begin{tabular}{|c|c|c|c|c|c|c|c|c|c|}
\hline \multirow{3}{*}{ No } & \multirow{3}{*}{$\begin{array}{l}\text { Pendidi } \\
\text { kan }\end{array}$} & \multicolumn{6}{|c|}{ Pengetahuan } & \multicolumn{2}{|c|}{ Jumlah } \\
\hline & & \multicolumn{2}{|c|}{ Baik } & \multicolumn{2}{|c|}{ Cukup } & \multicolumn{2}{|c|}{$\underset{\mathbf{g}}{\text { Kuran }}$} & \multirow{2}{*}{$\mathbf{F}$} & \multirow{2}{*}{$\%$} \\
\hline & & $\mathbf{F}$ & $\%$ & $\mathbf{F}$ & $\%$ & $\mathbf{F}$ & $\%$ & & \\
\hline 1 & SD & 1 & $\begin{array}{c}3,2 \\
\%\end{array}$ & 7 & $\begin{array}{c}22.6 \\
\%\end{array}$ & 3 & $\begin{array}{c}9,6 \\
\%\end{array}$ & 1 & $35,5 \%$ \\
\hline 2 & SMP & 1 & $\begin{array}{c}3,2 \\
\%\end{array}$ & 2 & $6,5 \%$ & 1 & $\begin{array}{c}3,2 \\
\%\end{array}$ & 4 & $12,9 \%$ \\
\hline 3 & SMA & 1 & $\begin{array}{c}3,2 \\
\%\end{array}$ & 4 & $\begin{array}{c}12,9 \\
\%\end{array}$ & 2 & $\begin{array}{c}6,5 \\
\%\end{array}$ & 7 & $22,6 \%$ \\
\hline 4 & P T & 2 & $\begin{array}{c}6,5 \\
\%\end{array}$ & 6 & $\begin{array}{c}19,4 \\
\%\end{array}$ & 1 & $\begin{array}{c}3,2 \\
\%\end{array}$ & 9 & $29 \%$ \\
\hline & umlah & 5 & $\begin{array}{c}16, \\
1 \\
\%\end{array}$ & 19 & $\begin{array}{c}61,4 \\
\%\end{array}$ & 7 & $\begin{array}{c}22,5 \\
\%\end{array}$ & $\begin{array}{l}3 \\
1\end{array}$ & $100 \%$ \\
\hline
\end{tabular}

Berdasarkan tabel 7 di atas dapat dilihat bahwa dari 31 responden yang berpendidikan SD sebanyak 11 responden (35,5\%), dengan pengetahuan baik sebanyak 1 responden $(3,2 \%)$, pengetahuan cukup sebanyak 7 responden $(22,6 \%)$, pengetahuan kurang sebanyak 3 responden $(9,7 \%)$. Responden yang bependidikan SMP sebanyak 4 responden (12,9\%), dengan pengetahuan baik sebanyak 1 responden (3,2\%), pengetahuan cukup 2 responden $(6,5 \%)$, dan pengetahuan kurang 1 responden $(3,2 \%)$. Responden yang berpendidikan SMA sebanyak 7 responden $(22,6 \%)$, dengan pengetahuan baik sebanyak 1 responden $(3,2 \%)$, pengetahuan cukup sebanyak 4 responden $(12,9 \%)$, pengetahuan kurang sebanyak 2 responden $(6,5 \%)$. Responden yang berpendidikan Perguruan Tinggi berjumlah 9 responden (29\%), dengan pengetahuan baik sebanyak 2 responden $(6,5 \%)$, pengetahuan cukup sebanyak 6 responden $(19,4 \%)$, dan pengetahuan kurang sebanyak 1 responden $(3,2 \%)$.

\section{H. Distribusi Responden Berdasarkan Pekerjaan}

Tabel 8. Distribusi Frekuensi Responden Tentang Terjadinya Stomatitis pada balita Berdasarkan Pekerjaan di Lingkungan I KelurahanSigalangan Kecamatan Batang Angkola Tahun 2018

\begin{tabular}{cccccccccc}
\hline & & \multicolumn{4}{c}{ Pengetahuan } & \multicolumn{3}{c}{ Jumlah } \\
No & Pekerjaan & \multicolumn{2}{c}{ Baik } & \multicolumn{2}{c}{ Cukup } & \multicolumn{2}{c}{ Kurang } & F & \% \\
& & F & $\mathbf{\%}$ & F & \% & F & \% & & \\
1 & Petani & 3 & $9,6 \%$ & 11 & $35,5 \%$ & 4 & $12,9 \%$ & 18 & $58 \%$ \\
2 & PNS & 2 & $6,5 \%$ & 7 & $22,5 \%$ & 0 & $0 \%$ & 9 & $29 \%$ \\
3 & Wiraswasta & 0 & $0 \%$ & 2 & $6,5 \%$ & 2 & $6,5 \%$ & 4 & $13 \%$ \\
& Jumlah & $\mathbf{5}$ & $\mathbf{1 6 , 1 \%}$ & $\mathbf{2 0}$ & $\mathbf{6 4 , 5 \%}$ & $\mathbf{6}$ & $\mathbf{1 9 , 4 \%}$ & $\mathbf{3 1}$ & $\mathbf{1 0 0 \%}$ \\
\hline
\end{tabular}

Berdasarkan tabel 8 di atas dapat dilihat bahwa dari 31 responden yang pekerjaannya sebagai Petani berjumlah 18 responden (58\%), dengan pengetahuan baik sebanyak 3 responden $(9,6 \%)$, pengetahuan cukup sebanyak 11 responden $(35,5 \%)$, pengetahuan kurang sebanyak 4 responden 
(12,9\%). Responden yang pekerjaannya sebagai PNS sebanyak 9 responden (29\%), dengan pengetahuan baik sebanyak 2 responden (6,5\%), pengetahuan cukup sebanyak 7 responden $(25,5 \%)$, pengetahuan kurang tidak ada. Responden yang pekerjaannya sebagai Wiraswasta sebanyak 4 responden (13\%), dengan pengetahuan baik tidak ada, pengetahuan cukup sebanyak 2 responden $(6,5 \%)$, pengetahuan kurang sebanyak 2 responden $(6,5 \%)$.

\section{Distribusi Responden Berdasarkan Sumber Informasi}

Tabel 9. Distribusi Frekuensi Responden Tentang Terjadinya Stomatitis pada balita Berdasarkan Sumber Informasi di Lingkungan I Kelurahan Sigalangan Kecamatan Batang Angkola Tahun 2018

\begin{tabular}{|c|c|c|c|c|c|c|c|c|c|}
\hline \multirow{3}{*}{ No } & \multirow{3}{*}{$\begin{array}{l}\text { Sumber } \\
\text { Informasi }\end{array}$} & \multicolumn{6}{|c|}{ Pengetahuan } & \multicolumn{2}{|c|}{ Jumlah } \\
\hline & & \multicolumn{2}{|c|}{ Baik } & \multicolumn{2}{|c|}{ Cukup } & \multicolumn{2}{|c|}{ Kurang } & $\mathbf{F}$ & o \\
\hline & & $\mathbf{F}$ & $\%$ & $\mathbf{F}$ & $\%$ & $\mathbf{F}$ & $\%$ & & \\
\hline 1 & Media Cetak & 3 & $9,7 \%$ & 6 & $19,4 \%$ & 0 & $0 \%$ & 9 & $29 \%$ \\
\hline 2 & $\begin{array}{r}\text { Media } \\
\text { Elektron }\end{array}$ & & & 9 & $29 \%$ & & $16,1 \%$ & 14 & $45,2 \%$ \\
\hline 3 & $\begin{array}{l}\text { Petugas } \\
\text { Kesehatan }\end{array}$ & 2 & $6,5 \%$ & 5 & $16,1 \%$ & 1 & $3,2 \%$ & 8 & $25,8 \%$ \\
\hline & Jumlah & & $16,2 \%$ & 20 & $64,5 \%$ & 6 & $19,3 \%$ & 31 & $100 \%$ \\
\hline
\end{tabular}

Berdasarkan tabel 9 di atas dapat dilihat dari 31 responden yang memperoleh Sumber Informasi dari Media Cetak sebanyak 9 responden (29\%), dengan pengetahuan baik sebanyak 3 responden $(9,7 \%)$, pengetahuan cukup sebanyak 6 responden $(19,4 \%)$, pengetahuan kurang sebanyak tidak ada. Responden yang memperoleh Sumber Informasi dari Media Elektronik sebanyak 14 responden $(45,2 \%)$, pengetahuan baik sebanyak tidak ada, pengetahuan cukup sebanyak 9 responden (29\%), pengetahuan kurang 5 responden $(16,1 \%)$. Dan responden yang memperoleh Sumber Informasi dari Petugas Kesehatan sebanyak 8 responden (25,8\%), dengan pengetahuan baik sebanyak 2 responden $(6,5 \%)$, dengan pengetahuan cukup sebanyak 5 responden $(16,1 \%)$, dan pengetahuan kurang sebanyak 1 responden $(3,2 \%)$.

\subsection{Pembahasan}

Pembahasan adalah kesenjangan yang muncul setelah penelitian kemudian membandingkan antara teori dengan hasil penelitian berdasarkan hasil penelitian yang berjudul "Faktor-Faktor yang mempengaruhi pengetahuan ibu tentang terjadinya stomatitis pada balita di lingkunga I kelurahan sigalangan kecamatan batang angkola tahun 2018" bahwa pengetahuan ibu adalah kategori cukup. Hal ini dapat dari beberapa faktor yang mempengaruhi pengetahuan responden yaitu berdasarkan umur, pendidikan, pekerjaan, sumber informasi.

\section{A. Berdasarkan Pengetahuan}

Berdasarkan tabel 1 dapat dilihat dari 31 responden mayoritas berpengetahuan cukup 20 responden $(64,5 \%)$, dengan kategori berpengetahun kurang 6 responden $(19,4 \%)$. Dan minoritas responden berpengetahuan baik 5 responden $(10 \%)$. Hal ini dapat dilihat dari beberapa hal yaitu berdasarkan umur, pendidikan, pekerjaan, sumber informasi. Menurut Notoadmodjo (2010) yang mengatakan bahwa pengetahuan adalah hasil penginderaan manusia, atau hasil tahu seseorang terhadap objek melalui indra yang dimilikinya (mata, hidung, telinga, dan sebagainya).

Menurut mubarak (2012), Pengetahuan adalah kesan di dalam pikiran manusia sebagai hasil penggunaan pancaindranya. Pengetahuan sangat berbeda dengan kepercayaan, takhayul dan penerangan-penerangan yang keliru. Menurut peneliti pengetahuan yang di peroleh seorang ibu tentang stomatitis (sariawan) pada balita dikategorikan berpengetahuan cukup, akibatnya banyak ibu yang tidak mengetahui betapa pentingnya stomatitis pada balita. Dari pernyataan di atas dapat disimpulkan bahwa hasil penelitian diatas sejalan dengan pendapat para ahli.

\section{B. Pengetahuan Responden Berdasarkan Umur}

Berdasakan tabel 6 menunjukkan bahwa dari 31 responden yang diteliti mayoritas berumur 24-28 sebanyak 11 responden $(35,5 \%)$ dengan katogori berpengetahuan baik tidak ada, yang berpengetahuan cukup sebanyak 8 responden $(28,5 \%)$, dan yang berpengetahuan kurang sebanyak 3 responden $(9,7 \%)$. Sedangkan minoritas responden berumur 29-33 tahun sebanyak 9 responden (29\%) dengan katogori berpengetahuan baik sebanyak 5 responden $(16,1 \%)$, yang berpengetahuan cukup sebanyak 3 responden $(9,7 \%)$, dan yang berpengetahuan kurang sebanyak 1 responden $(3,2 \%)$. 
Menurut Satria (2008), Dengan bertambahnya umur seorang ibu akan terjadi perubahan pada aspek psikis dan psikologi (mental) akibat pematangan fungsi seorang ibu semakin matang dan dewasa tentang terjadinya Stomatitis pada balita.

Menurut Arini (2009) umur merupakan usia individu yang terhitung mulai saat lahir sampai berulang tahun. Semakin cukup umur maka tingkat pengetahuan dan kekuatan seorang akan lebih matang dan berfikir dan bekerja.

Menurut peneliti, semakin bertambah umur seseorang itu semakin banyak pengalaman dan informasi yang diterimanya sehingga menambah pengetahuan. Tapi tidak selamanya seseorang yang berumur tua mempunyai pengetahuan baik karena kemampuan penerimaan atau daya ingat akan menurun, sehingga pengetahuannya berkurang. Dari pernyataan diatas dapat disimpulkan bahwa teori tidak sesuai dengan hasil penelitian.

\section{Pengetahuan Responden Berdasarkan Pendidikan}

Berdasarkan tabel 7 menunjukkan bahwa dari 31 responden yang diteliti mayoritas berpendidikan SD sebanyak 11 responden $(35,5 \%)$ dengan katagori yang berpengetahuan baik sebanyak 1 responden $(3,2 \%)$, yang berpengetahuan cukup sebanyak 7 responden $(22,6 \%)$ dan yang berpengetahuan kurang sebanyak 3 responden $(9,6 \%)$. Sedangkan minoritas responden berpendidikan SMP 4 responden (12,9\%), dengan katagori yang berpengetahuan baik sebanyak 1 responden $(3,2 \%)$, yang berpengetahuan cukup sebanyak 2 responden $(6,5 \%)$, dan yang berpengetahuan kurang 1 responden $(3,2 \%)$.

Menurut Wawan \& Dewi (2010). Pendidikan adalah bimbingan yang diberikan seseorang terhadap perkembangan orang lain menuju kearah cita-cita tertentu yang menentukan manusia untuk membuat dan mengisi kehidupan untuk mencapai keselamatan dan kebahagian. Pendidikan dapat mempengaruhi pengetahuan seseorang akan pola hidup terutama dalam memotivasi untuk bersikap berperan serta dalam pembangunan.

Menurut peneliti bahwa pendidikan sangat mempengaruhi ibu tentang terjadinya stomatitis pada balita, karena semakin tinggi pendidikan ibu maka semakin mengerti bagaimana cara menghindari agar balia tidak terkena stomatitis. Dari pernyataan diatas dapat disimpulkan bahwa teori tidak sesuai dengan hasil penelitian.

\section{Pengetahuan Responden Berdasarkan Pekerjaan}

Berdasarkan tabel 8 menunjukkan bahwa dari 31 responden yang diteliti mayoritas responden yang memiliki pekerjaan sebagai petani sebanyak 18 responden $(58 \%)$ dengan katagori berpengetahuan baik sebanyak 3 responden $(9,6 \%)$, yang berpengetahuan cukup sebanyak 11 responden $(35,5 \%)$, dan yang berpengetahuan kurang sebanyak 4 responden $(12,9 \%)$. Sedangkan minoritas responden yang memiliki pekerjaan sebagai wiraswasta sebagai sebanyak 4 responden (13\%) dengan katagori yang berpengetahuan baik tidak ada, yang berpengetahuan cukup sebanyak 2 responden $(6,5 \%)$, dan yang berpengetahuan kurang sebanyak 2 responden $(6,5 \%)$

Menurut Mubarak (2012), lingkungan pekerjaan dapat membuat seseorang memperoleh pengalaman dan pangetahuan, baik secara langsung maupun tidak langsung. Menurut wawan (2011) pekerjaan adalah keburukan yang harus di lakukan terutama untuk menunjang kehidupannya dan kehidupan keluarga.

Menurut peneliti, pekerjaan itu tidak selamanya mempengaruhi pengetahuan karena tidak semua di tempat kerja bisa banyak mendapatkan pengetahuan tentang kesehatan sariawan pada balita. Dari pernyataan diatas dapat disimpulkan bahwa teori tidak sesuai dengan hasil penelitian.

\section{E Pengetahuan Responden Berdasarkan Sumber Informasi}

Berdasarkan tabel 9 menunjukkan, bahwa dari 31 responden yang diteliti mayoritas mendapatkan informasi dari media Elektronik sebanyak 14 responden $(45,2 \%)$ dengan katagori yang berpengetahuan baik tidak ada, yang berpengetahuan cukup sebanyak 9 responden (29\%), dan yang berpengetahuan kurang sebanyak 5 responden (16,1\%). Sedangkan minoritas responden mendapatkan informasi dari Petugas Kesehatan sebanyak 8 responden $(25,8 \%)$ dengan katagori yang berpengetahuan baik sebanyak 2 responden (6,5\%), yang berpengetahuan cukup sebanyak 5 responden $(16,1 \%)$, dan yang berpengetahauan kurang sebanyak 1 responden $(3,2 \%)$.

Menurut mubarak (2012) kemudahan memperoleh informasi dapat membantu mempercepat seseorang memperoleh pengetahuan yang baru. Menurut Ramadhan (2009), informasi yang 
diperoleh baik dari pendidikan formal maupun non formal dapat memberikan pengaruh jangka pendek (immediate impact) sehingga menghasilkan perubahan atau peningkatan pengetahuan. Majunya tekhnologi akan tersedia bermacam-macam media massa yang dapat mempengaruhi pengetahuan masyarakat tentang inovasi baru.

Menurut peneliti seseorang yang cenderung mendapatkan informasi melalui media eloktronik seperti $\mathrm{TV}$, radio tetapi tidak selamanya mendapatkan informasi tentang stomatitis pada balita. Dari pernyataan diatas dapat disimpulkan bahwa teori sesuai dengan hasil penelitian.

\section{KESIMPULAN}

Berdasarkan hasil penelitian yang telah penulis lakukan dengan judul "Faktor-faktor Yang Mempengaruhi Pengetahun Ibu Tentang Terjadinya Stomatitis pada balita di Lingkungan I Kelurahan Sigalangan Kecamatan Batang Angkola Tahun 2018”. Bahwa penulis dapat mengambil kesimpulan sebagai berikut : Faktor-faktor yang Mempengaruhi Pengetahuan Ibu Tentang Terjadinya Stomatitis pada balita di Lingkungan I Kelurahan Sigalangan Kecamatan Batang Angkola Tahun 2018, bahwa dari 31 responden mayoritas berpengetahuan cukup sebanyak 20 responden $(64,5 \%)$, dan minoritas berpengetahuan kurang sebanyak 6 responden $(19,4 \%)$. Faktor-faktor yang Mempengaruhi Pengetahuan Tentang Terjadinya Stomatitis pada balita di Lingkungan I kelurahan Sigalangan Kecamatan Batang Angkola Tahun 2018, dari 31 responden responden mayoritas berumur 24-28 tahun sebanyak 11 responden (35,5\%), dan minoritas 29-33 tahun sebanyak 9 responden (29\%). Faktor-faktor yang Mempengaruhi Pengetahuan Ibu Tentang Terjadinya Stomatitis di Lingkungan I Kelurahan Sigalangan Kecamatan Batang Angkola Tahun 2018, dari 31 responden berdasarkan pendidikan, mayoritas berpendidikan SD sebanyak 11 responden $(35,5 \%)$, dan minoritas responden berpendidikan SMP sebanyak 4 responden (12,9\%). Faktor-faktor yang Mempengaruhi Pengetahuan Ibu Tentang Terjadinya Stomatitis pada balita di Lingkungan I Kelurahan Sigalangan Kecamatan Batang Angkola Tahun 2018, dari 31 responden responden mayoritas berdasarkan pekerjaan sebagai Petani sebanyak 18 responden $(58 \%)$, dan minoritas bekerja sebagai wiraswasta sebanyak 4 responden (12,9\%). Faktor-faktor yang Mempengaruhi Pengetahuan Ibu Tentang Terjadinya Stomatitis pada balita di Lingkungan I Kelurahan Sigalangan Kecamatan Batang Angkola Tahun 2018, dari 31 responden mayoritas Berdasarkan sumber informasi dari media eloktronik sebanyak 14 responden $(45,2 \%)$, dan minoritas responden mendapat informasi dari petugas kesehatan sebanyak 8 responden $(25,8 \%)$.

\section{REFERENSI}

Arief \& Kristianasari, w. (2009). Neonatus dan Asuhan Keperawatan Anak. Yogyakarta : Nuha Offset.

Arini H. (2012). Mengapa Seorang Ibu Harus Menyusui. Jogjakarta: Flasbook

Arikunto,(2006). Prosedur Suatau Pendekatan Praktik. Jakarta : Rineka Cipto.

Kristianasari weni, (2011). Asuhan keperawatan neonatus. Yogyakarta : Nuha Medika

Mumpuni,y, pratiwi, (2013). Masalah dan Solusi Penyakit Gigi Dan Mulut. Yogyakarta : Rapha Publishing.

Mubarak Iqbal Wahit. (2012). Promosi Kesehatan Untuk Kebidanan. Jakarta : selemba medika.

Muttaqim, a \& sari, k, (2011). Gangguan Gastrointestinal Aplikasi Asuhan Keperawatan Medikal Bedah. Jakarta : Salemba Medikal.

Notoajmojo, Soekkijo, (2007). Promosi Kesehatan Dan Ilmu Prilaku. Rineka Cipta. Yogyakarta : Nuha Medika Notoatmojo, Soekkijo, (2005). Metode Penelitian Kesehatan. Jakarta : Rineka Cipto.

Notoatmojo, Soekkijo, (2010). Ilmu Prilaku Kesehatan. Jakarta : Rineka Cipta.

Rochman, dkk, (2011). Asuhan Neonatus, Bayi Dan Balita. Jakarta : Kedokteran Egc.

Rahmadan. (2009). Pengetahuan dan Faktor-Faktor Yang Mempengaruhi.

Satria. (2008). Faktor-faktor yang Mempengaruhi Pengetahuan. Yogyakarta : Nuha Medika.

Sudijono, a. (2008). Pengantar Statistik Pendidikan. Jakarta : pt. Raja Granfindo Persada

Suparyanto, (2012). Hubungan keperawatan. Yogyakarta : Nuha Medika.

Tilong, Adi, (2012). Deteksi Gangguan Kesehatan Dengan Lidah, Bau Nafas Dan Urine. Jakarta. Buku Biru. Wawan, A \& Dewi, M. (2010). Teori pengukuran dan pengetahuan sikap dan prilaku manusia.

Ai Yeyeh Rukiah S,SSt, MKM \& Lia Yulianti. (2011). Asuhan Kebidanan Dan Kehamilan. Jakarta CV. Trans Info Media.

Anonim, (2011).http//repository.usu.ac. Id/bistream/123456789/27233/4/ch apter\%2011.pdf(akses tanggal 7 maret 2018). 